Whigham, S

The SNP, Scottish Labour and Glasgow 2014 - Contrasting Political Narratives of the 2014 Commonwealth Games

Whigham, S (2017) The SNP, Scottish Labour and Glasgow 2014 - Contrasting Political Narratives of the 2014 Commonwealth Games. Scottish Affairs

doi: awaiting

This version is available: https://radar.brookes.ac.uk/radar/items/15dadbb6-02ed-4767-8ccf-e2404ce1b0f9/1/

Available on RADAR: February 2017

Copyright (C) and Moral Rights are retained by the author(s) and/ or other copyright owners. A copy can be downloaded for personal non-commercial research or study, without prior permission or charge. This item cannot be reproduced or quoted extensively from without first obtaining permission in writing from the copyright holder(s). The content must not be changed in any way or sold commercially in any format or medium without the formal permission of the copyright holders.

This document is the postprint version of the journal article. Some differences between the published version and this version may remain and you are advised to consult the published version if you wish to cite from it. 


\title{
The SNP, Scottish Labour and Glasgow 2014 - Contrasting Political Narratives of the 2014 Commonwealth Games
}

\section{Stuart Whigham}

\begin{abstract}
This article critically examines the predominant narratives which emanate from political discourse in relation to two significant events in Scotland in 2014 - the Glasgow Commonwealth Games and the independence referendum. This article uses an analysis of the political discourse from the two largest parties in the Scottish Parliament at the time of the Games, the pro-independence Scottish National Party (SNP) and the pro-union Scottish Labour Party, to highlight the contrasting discursive strategies of each party within their manifestos, policy documents, press releases and parliamentary speeches. This analysis demonstrates that each party portrayed nuanced positions on the Games, with the SNP illustrating the constraining nature of the constitutional status quo in relation to the potential economic and social benefits of the Games, and Labour using the event to illustrate the effectiveness of their stewardship of the Glasgow City Council despite the council funding cuts imposed by the SNP-led Scottish Government. Despite acknowledging the marginal status of the Games on the eventual outcome of the referendum, both parties suggested that the success of the event could lead to a 'feel-good factor' which could boost the 'Yes' vote. Such questionable claims are evaluated in light of past academic studies which question the validity of legacy outcomes from sporting events such as the Games (e.g. Giulianotti, 2016; Horne, 2007; Horne and Manzenreiter, 2006; Martin and Barth, 2013; Stewart and Rayner, 2016; Zimbalist, 2015).
\end{abstract}

Key words: Commonwealth Games, Scottish independence, Scottish National Party, Scottish Labour Party, politics of sport, political discourse, narratives

Stuart Whigham is a Teaching Fellow in Sport, Coaching and Physical Education at Oxford Brookes University. Stuart is currently completing doctoral studies at Loughborough University under the supervision of Professor Alan Bairner, with a specific focus upon the politics of the 2014 Glasgow Commonwealth Games. Stuart's research interests revolve around the sociology and politics of sport, with a particular interest in national identity, nationalism and sport, the politics of sport and the Commonwealth Games, and the sociology and politics of Scottish sport. 


\section{Introduction}

This article critically examines the predominant narratives which emanate from political discourse in relation to two significant events in Scotland in 2014 - the Glasgow Commonwealth Games and the independence referendum. Given the importance of the referendum and its proximity to the Games, it is unsurprising that the event became intertwined with political positioning from parties on both sides of the constitutional debate. However, following Lord McConnell's appeal for a political 'truce' in the form of a temporary halt to campaigning regarding the independence referendum during the 2014 Games (BBC News, 2014), this article will also scrutinise the continued perpetuation of arguments supporting an apolitical approach to sport and the hosting of international sporting events. Although parties on both sides of the debate attempted to place emphasis on the apolitical nature of the Games, comments regarding the Games from Scottish National Party (SNP) politicians such as Alex Salmond and Nicola Sturgeon drew opprobrium from opposition politicians (Boffey, 2014; Wade, 2014), thus demonstrating the complex relationship between sporting events and political communication.

In light of this, this article will specifically examine the ways in which the hosting of the 2014 Games was used as a means of illustrating each party's political position in relation to the independence referendum. In particular, this article scrutinises the extent to which the staging of the Games in Scotland was exploited politically in relation to debates about Scotland's constitutional future by the two largest political parties at the time of the Games, the SNP and the Scottish Labour Party (referred to as Labour henceforth). Whilst the hosting of the Commonwealth Games should only 
be viewed as one issue amongst many within the constitutional debate and should therefore not be overstated in terms of its significance, the specific focus of its role in this important political debate facilitates the opportunity to complement the extensive array of academic literature on the political uses of sports event hosting (e.g. Holt and Ruta, 2015; Horne and Manzenreiter, 2006; Zimbalist, 2015).

\section{The Politics of Hosting the Commonwealth Games}

Despite frequent attempts by governments and politicians to stress their independence from political considerations (Jeffreys, 2012), numerous case studies of international sports events have identified instances where political influences have ramifications for these events (Horne, 2007; Horne and Manzenreiter, 2006; Jeffreys, 2012). Grix (2014) cites a number of prominent reasons why political actors have supported the hosting of sports mega-events, ranging 'from increasing sport participation among the population, urban regeneration, producing a 'feelgood factor' among citizens, to showcasing a nation on the world stage and, of course, making a profit' (2014: x). In particular, the 'showcasing' of nations highlighted by Grix has been emphasised in many recent academic analyses of contemporary sporting mega-events, drawing upon Nye's (2004) conceptualisation of 'soft power' and its growing importance in global

politics (Almeida et al., 2014; Brannagan and Giulianotti, 2014; Cornelissen, 2010: Grix, 2013; Grix and Houlihan, 2013; Manzenreiter, 2010; Mishra, 2012, 2013).

Academic studies have highlighted a range of political issues related to the Commonwealth Games historically, including the interconnections between the Games and the decolonialisation of the British Empire (e.g. Holt, 1989; Houlihan, 
1994; Polley, 2014), the impact of Games boycotts linked to the South African apartheid regime (e.g. Dheenshaw, 1994; Jeffreys, 2012; Kidd, 1988), and the more recent use of the Games for economic 'boosterism', urban regeneration and/or image projection (e.g. Black, 2014; Grix, 2014; Holt, 1989; Majumdar and Mehta, 2010). However, the notion of using major sporting events as part of a strategy of 'boosterism' has been argued by many academics to be based upon a flawed logic which ignores the lack of evidence of long-term benefits of hosting such events (Giulianotti, 2016; Horne, 2007; Horne and Manzenreiter, 2006; Martin and Barth, 2013; Stewart and Rayner, 2016; Zimbalist, 2015)

Scotland's past hosting of the Games has also been considered in past academic studies of the event. The 1986 Games were the second time the event was hosted in Edinburgh, and it had been hoped that the 1986 Games would emulate the relative success of Edinburgh's previous hosting of 'The Friendly Games' in 1970 which had been argued to have left a positive impact on the city due to its resultant infrastructure and sporting facility improvements (Bateman and Douglas, 1986; Dheenshaw, 1994; Majumdar and Mehta, 2010). However, the 1986 Edinburgh Games were unable to stave off the renewed threat of boycotts by a number of Commonwealth nations, resulting from the issue of British sporting contacts with the South African regime (Dheenshaw, 1994; Holt, 1989; McDowell and Skillen, 2017). The implications of the boycott were further compounded by the resultant financial difficulties faced by the organising committee (Bateman and Douglas, 1986; Dheenshaw, 1994; McDowell and Skillen, 2017).

Sport, Scottish Politics and the Glasgow 2014 Commonwealth Games 
Following the re-establishment of the Scottish Parliament in 1999, Scotland, and particularly Glasgow, have actively pursued a range of sporting events as part of an economic development strategy underpinned by tourism promotion, infrastructural improvements and urban regeneration (Christie and Gibb, 2015; Matheson, 2010; Mooney et al., 2015). Black (2014) argues that 'second-order' events such as the 2014 Glasgow Games are of great importance to 'locales for whom second-order games at the only realistic means of pursuing event-centred development strategies' (2014: 16), given that any attempts to 'springboard' to larger sporting events (as was the case of Kuala Lumpur 1998 or Delhi 2010) is infeasible for smaller host nations such as Scotland (Horne, 2017). Indeed, image projection and tourism promotion has been widely contended to form a central tenet of the 2014 Games legacy strategy (Clark and Kearns, 2016; Horne, 2017; Matheson, 2010; Owe, 2012; Rogerson, 2016).

However, Owe's (2012) review of evidence of past event legacies mirrored the findings of others, concluding that legacy evaluations of past events lacked robust evidence or had mixed evidence regarding their positive impact (Horne, 2007; Martin and Barth, 2013; McCartney et al., 2012; Mooney et al., 2015; Stewart and Rayner, 2016). Furthermore, other analyses have cautioned against the commonly-held perceptions about the possibility of a 'trickle-down effect' in terms of using funding for elite level sporting competitions to boost community sports and physical activity participation (Clark and Kearns, 2016), whilst others urge caution on the validity of claims regarding the 'feel-good effect' of hosting events such as the Games (Matheson, 2010; McCartney et al., 2012; Owe, 2012; Stewart and Rayner, 2016). 
This is problematic for achieving the planned legacy of the Games, given the centrality of using the Games to boost sports and physical activity participation to improve health outcomes in the Glaswegian and Scottish population (McCartney et al., 2012; Rogerson, 2016), or to overcome barriers relating to disability sports participation (McPherson et al., 2016; Misener et al., 2015).

Other academic reflections on the hosting of the 2014 Games have also been critical in tone. For example, Gray and Porter's (2015) analysis of the use of Compulsory Purchase Orders (CPOs) to secure land for Games-related infrastructure and facilities highlight the exploitation of the 'state of exception' created by hosting major events by the Scottish Government and Glasgow City Council to forcibly remove residents from socially deprived areas such as Dalmarnock. Paton et al. (2012) are equally critical of the underpinning ideologies which inform the Scottish Government's approach to regeneration through the Games. They argue that these assumptions draw upon neoliberal principles, arguing that they result in market-led economic and social development strategies. This therefore invokes the 'trickle-down' belief regarding the use of sporting events for development purpose, with Paton et al. (2012) aligning with the arguments of others regarding the fallacy of such beliefs (Clark and Kearns, 2016; Matheson, 2010; Mooney et al., 2015; Owe, 2012; Stewart and Rayner, 2016). Gray and Mooney (2011) are therefore sceptical about this depiction of the Games, arguing that:

...the discourse of regeneration, the engineering of collective hyperbole around the Commonwealth Games and the advancement of the 'Team Glasgow' mantra, operate as both placebo for genuine participation models, and as alibis for property-led regeneration activity and punitive labour market policy. (2011: 19) 
These arguments are symptomatic of the central arguments of critics of the official political narratives regarding the legacy of the 2014 Games which often fail to acknowledge the mixed evidence about the legacy of past events, with a consensus emerging in academic studies which questions the extent to which the economic and social benefits of the event will effectively prioritise the local population (Clark and Kearns, 2016; Gray and Mooney, 2011; Gray and Porter, 2015; Martin and Barth; 2013; Mooney et al., 2015; Paton et al., 2012).

\section{The 2014 Commonwealth Games and the Scottish Independence Referendum}

Attention now turns to studies which have explicitly considered the interconnection between the 2014 Games and the independence referendum. Jarvie's (2017) chapter on the interconnection between the Games, Scottish sport and the independence referendum represents the most extensive articulation of this relationship to date. However, Jarvie concluded that the event remained a marginal event in the referendum campaigns, highlighting that 'the Yes and No camps strived for political advantage while not wanting to be seen to be overtly using the Games to deliver referendum messages' (2017: 219). Whilst acknowledging arguments that the Games could result in a 'feel-good' factor which could influence the outcome, Jarvie also cited the findings of opinion polling which highlighted the limited impact of the Games on referendum voting intentions (Survation, 2014). Jarvie (2017: 219) therefore concluded that the 'realpolitik of Glasgow 2014 was not so much about local referendum politics but saving the future of the Commonwealth Games... 
during the Scottish referendum campaign sport was neither a driver of cultural or political nationalism nor a hotly contested political issue'.

Ochman's (2013) reflections on the political implications of the Games identifies similar issues to the work of Jarvie (2017), highlighting the concerns of elite athletes regarding the potential implications of Scottish independence and echoing Jarvie's comments on the marginal impact on referendum voting intention. Nonetheless, in contrast to Jarvie, Ochman contends that:

...it is more than probable that the Games will be used by the Scottish government as a powerful tool in the battle for independence. For First Minister Alex Salmond and his Scottish National Party, sport events constitute a unique occasion to underline Scottish autonomy. (2013: 78)

Ochman bases this contention on her observations of the SNP's responses to the symbolism of the London 2012 Olympics, highlighting Alex Salmond's attempts to distinguish the success of Scottish athletes of those of 'Scolympians' rather than members of 'Team GB'. Harris and Skillen's (2016) reflection on the interconnection between sport and the referendum places similar emphasis on the nature of these political interventions regarding the Olympics, contending that ' $[\mathrm{w}] \mathrm{ith}$ the referendum looming ever closer, it was clear that competing claims for these medal winners was going to become an ever-present issue' (ibid: 84). This highlights the potentially dualistic symbolism of major sporting events such as the Olympics and the Commonwealth Games, given their associations with both Britishness and Scottishness (Iorwerth et al., 2014; Jarvie and Reid, 1999; McDowell and Skillen, 2017; Polley, 2014). Harris and Skillen's (2016) reflection on the politicisation of sport vis-à-vis the referendum placed particular emphasis on the role of the media in 
raising these potentially contentious issues in their comments on the Games. To this end, Harris and Skillen remarked that the media 'would also at times actively look for an angle whereby they could weave the issue of independence into narratives of sporting success' (2016: 92).

In contrast, Mole's (2014) brief editorial on the interconnection between the Games and the referendum drew similar conclusions to Jarvie (2017) and Ochman (2013) on the lack of political impact of the Games on the outcome of the vote, highlighting that '[c]oming towards the end of the Scottish referendum campaign, the Games avoided politics but allowed both the 'Yes' camp and the 'Better Together' campaign to draw comfort' (2014: 453), alluding to the campaign break which materialised during the Games period. However, Mole also speculates that the fact that Glasgow was one of the few areas which had a majority of 'Yes' votes could be partly attributed to the success of the Games. However, the lack of empirical evidence in the account of Mole (2014), as is the case with Ochman (2013), Jarvie (2017) and Harris and Skillen (2016), means that the extent to which their claims regarding the interconnection between these two events require further empirical investigation.

\section{Methodology}

The crux of the methodological approach underpinning the findings of this article lie in its emphasis on analysing the content of political discourse relating to the Scottish independence referendum and the 2014 Commonwealth Games, as well as the identification of predominant narrative forms within the discourse of the SNP and Labour. In particular, this methodological approach is derived from the principles of 
critical discourse analysis (CDA) and narrative analysis, applying Fairclough and Fairclough's (2012) framework for political discourse analysis to explore the interconnection between the respective narratives of the 2014 Games and the political argumentation of each party vis-à-vis the independence referendum. This strategy facilitates the opportunity to ideologically contextualise discourse from the selected parties which specifically relate to the 2014 Commonwealth Games. This two-tiered analysis facilitates a nuanced understanding of the political values which are evident in each party's stance on the political ramifications of the Games, as these issues are framed within each party's wider political vision concerning Scotland's constitutional future. This methodological approach is therefore grounded in the assumption that the contrasting constitutional stances of the pro-independence SNP and the pro-union Labour Party will be reflected in their discursive framing of the Games.

The first stage of the data collection process involved scrutinising political discourse which specifically discussed the 2014 Glasgow Commonwealth Games. It was decided therefore to delineate sources which could be deemed reflective of 'official' political communication sources. Therefore, the data sample was restricted to press releases, speech transcripts and policy publications which were produced directly by politicians and political parties. The first stage of narrowing the data sample involved specifically identifying forms of political communication which met the following inclusion criteria:

- Takes form of official press release, party webpage, speech transcript, parliamentary contribution, political manifesto, or policy document 
- Has a publication date between $23^{\text {rd }}$ March 2011 (dissolution of $3^{\text {rd }}$ Scottish Parliament) and $18^{\text {th }}$ September 2014 (date of Scottish independence referendum)

- $\quad$ Produced by the SNP or Labour

- Included the phrases 'Commonwealth Games', 'Games' or 'Commonwealth'

These inclusion criteria were deemed necessary for a number of reasons. By restricting the data sample to sources which have been released from official party channels, it was possible to specifically scrutinise examples of communication which have been officially sanctioned by press officials and campaign staff. The decision to restrict the sample to sources with a publication date between $23^{\text {rd }}$ March 2011 and $18^{\text {th }}$ September 2014 allowed for reflection on the political discourse leading into the 2011 Scottish Parliamentary elections, whilst equally allowing for the inclusion of pre-referendum political discourse from the fourth sitting of the Scottish Parliament leading into the 2014 Games and the independence referendum respectively. It is acknowledged that this decision precluded the opportunity to explore the shifting constitutional 'imaginaries' of the respective parties in the post-referendum period, given the need for parties to respond to the 'No' vote in the referendum. However, given the emphasis of the article on the political exploitation of the Games to support the contrasting views of the party on the referendum, it was decided that the removal of post-referendum discourse would ensure that the emergent findings reflected the nature of the discourse during the actual period of the referendum.

As a result of the inclusion and exclusion criteria outlined above, the final data sample totalled 511 secondary data sources, consisting of 3 policy documents, 83 
official press releases, 419 oral contributions from MSPs in official Scottish Parliamentary sessions, and 6 party manifestos. Each data source was uploaded into the NVivo qualitative data analysis software package which was used to manually code the content of each data source, with an open coding system used to identify emergent themes, followed by an axial coding process which sought to categorise these lower-level codes into higher-level discursive forms using the framework proposed by Fairclough and Fairclough (2012).

The second stage of the data collection process involved interviews with four political representatives from the respective parties to provide an explanatory analysis of the strategies which informed the character of official political communication sources on the topic of the Games. To this end, a criterion-based purposive sampling strategy was adopted to delineate potential participants for primary data collection, with the participation of politicians restricted to serving MSPs during the period of the data sample outlined above. Participants were initially selected by identifying MSPs from both political parties with cross-party or committee parliamentary responsibilities in relation to the Commonwealth Games and/or sport, given that these participants could provide more detailed insights into this specific event and policy area. The invitation process continued until a maximum of two MSPs from the respective parties had agreed to participate in the study. However, in order to achieve this goal, it was also necessary to approach MSPs with representative responsibilities for the Glasgow constituencies and region, and, finally, to extend invitations to other MSPs without specific responsibilities for sport or the Glasgow region. 
Consent to de-anonymise the contributions was granted for all four participants (namely, Kenny MacAskill and John Mason for the SNP, and Patricia Ferguson and Drew Smith for Scottish Labour), and their names have been attributed to any quotes offered in the forthcoming discussion. The interviews were conducted within the period from April 2014 to October 2014 to overcome potential access difficulties, following responses from other potential participants who expressed concerns about participation prior to the referendum due to time pressures and/or political sensitivities. The interviews ranged from between 18 and 49 minutes in duration, and were transcribed verbatim at the initial stage of the data analysis process. A particular emphasis was placed on the strategic thinking and ideological values which underpinned the production of political communication relating to the Games and the independence referendum. The analysis of the interviews was then cross-referenced with the results of the secondary data analysis, identifying where similarities and discrepancies emerged in the emergent political narratives in the interviews in comparison to the political discourse associated with their respective parties.

\section{The SNP and the Politics of the Games - Sporting Infrastructure, Economic Boosterism and the 'Feel-Good Factor'}

Discussion commences with a consideration of the emergent discursive patterns within the SNP's publications and manifestos specifically relating to Scotland's constitutional status and the 2014 Games. The sample for the SNP was constituted of the Scottish Government's White Paper on Scottish independence, 3 election manifestos, plus 299 parliamentary speech contributions, and 66 press releases which make explicit reference to the Games. 
Analysis of the SNP's discourse sample identified sporting benefits as the most common category. The party argued for a range of sports-related legacy aspects deriving from the Games, with a primary focus on using the event as a catalyst for boosting sports and physical activity participation rates in Scotland (Clark and Kearns, 2016; McCartney et al., 2012; Rogerson, 2016). Frequent reference was made to the impact of the Games on the development of sporting facilities in Scotland:

...I am delighted to announce that there are now 72 hubs in the pipeline, with 41 community sports hubs up and running throughout Scotland... They cater to the local needs of each community and support participation in physical activity across the country. They demonstrate our commitment to ensuring that all Scotland's people and communities can benefit from becoming more active... Following the Commonwealth Games, Scotland will be a stronger sporting nation... (Shona Robison MSP, SP OR 21 December 2011, col. 4869)

Furthermore, enhanced support for youth sport provision and improvements to the elite sport performance system in Scotland were also forwarded as further prognostications about the impact of the Games.

Despite the centrality of these arguments in the SNP's discourse, the interviews revealed a more restrained perspective. John Mason highlighted a number of positive developments with regards to the sporting legacy of the Games, but equally cautioned about the delivery of a sporting legacy on two separate occasions:

There's quite a lot that's happening, but how big an impact it has on subjects like health I think remains to be seen, and I think every other city with Commonwealth or Olympic Games has struggled to do the 
legacy thing... (John Mason MSP, interview)

Furthermore, Kenny MacAskill made no direct reference to the sporting legacy of hosting the Games, despite listing numerous other benefits. This demonstrates that the centrality of the sporting legacy of the Games was not necessarily shared by all in the SNP, whether this be due to contrasting policy responsibilities or an unwillingness to emphasise sporting legacy due to historic failures elsewhere, including the case of Scotland's previous hosting of the Games in Edinburgh in 1970 and 1986 which has led to ongoing disputes on the use of Meadowbank Stadium (Reid, 2013, 2014). Given that analyses of sports participation data in Scotland in the period following the Games showed little improvement (Clark and Kearns, 2016; Rogerson, 2016; Scottish Government, 2015), the continued lack of concrete evidence suggests that politicians may be sensible to continue to act with caution.

The SNP also placed a significant emphasis on the benefits of the Games for the Scottish economy. Within this category, particular emphasis was placed on the use of the Games to encourage regeneration and infrastructural developments in Glasgow's 'East End':

This Government is absolutely clear about the contribution that regeneration makes to growing our economy and improving the life chances of Scotland's people. All these projects are central to the regeneration of the area and will contribute to the legacy of the Commonwealth Games. (Alex Salmond MSP, 'Multi-million pound regeneration boost', Scottish Government press release, 2014) 
Other frequently-cited economic benefits from the event included tourism revenues, enhanced employability and training, increased exports of Scottish produce, a significant proportion of Games-related contracts for Scottish businesses, and inward investment (Christie and Gibb, 2015; Clark and Kearns, 2016; Mooney et al., 2015). The centrality of economic justifications within the SNP's 'public narrative' is resonant with the work of academics who have identified the use of sporting megaevents as a means of 'economic boosterism' for the host city and nation (Holt, 1989; Horne, 2007; Horne and Manzenreiter, 2006; Zimbalist, 2015). Furthermore, this emphasis on economic considerations aligns with the party's ideological 'values', especially their attempts to project a position which is pro-business and focused on Scottish economic growth (Lynch, 2009; Tomlinson, 2014), whilst simultaneously raising Scotland's profile on an international basis in line with the arguments of past academic analyses of using sporting events as a form of 'soft power' (Almeida et al., 2014; Brannagan and Giulianotti, 2014; Cornelissen, 2010: Grix, 2013; Grix and Houlihan, 2013; Manzenreiter, 2010; Mishra, 2012, 2013).

Discussion in the political stakeholder interviews also demonstrated the centrality of economic considerations when justifying the government's investment in the Games:

It's first of all a chance to regenerate the East End of Glasgow which probably statistically is the poorest area of the country. The infrastructure and investment is phenomenal in the area over the years. (Kenny MacAskill MSP, interview)

However, despite the overwhelmingly positive messages in the SNP's discourse regarding the economic benefits of hosting the Games, the interviews revealed a disjuncture between rhetoric and reality. For example, despite being one of the most 
frequent contributors to the Scottish Parliament in terms of emphasising the economic and infrastructural benefits of the Games for his constituency, Mason questioned the validity of such claims in practice:

...there have been questions about... even in the construction phase, were there local jobs? Well, I think there were some but... I don't know, I think some people expected jobs maybe to just fall into their lap, or something, and that's not gonna happen. And somebody did say to me: "Right, that's the Games over... where's the legacy? Where's the regeneration of things?" (John Mason MSP, interview)

Nonetheless, despite these partial reservations about the extent of the economic benefits, both Mason and MacAskill expressed a generally supportive stance with regards to the Games' positive impact upon the local and national economy in a broader sense.

For the SNP, the Games also acted as an opportunity to illustrate wider political debates in Scotland. This tactic was used to illustrate various issues, with the investment in the Games used as an analogy for the SNP's general economic growth strategy, an example of the SNP's success in government, and an example of the success of the SNP's tourism strategy, amongst others:

That's why when my Government came into office in 2007, we focussed government activity on one purpose, 'to create opportunities for all of Scotland to flourish by raising the rate of sustainable economic growth'. It's not about growth alone, it's about sustainable growth for a purpose: the wellbeing and happiness of individuals and communities in every part of the country. The Commonwealth Games demonstrate our approach to growth. ('Scotland's international profile has never been higher', Scottish Government press release, 2014) 
On what the SNP has ever done for Glasgow, there is the new south Glasgow hospital, the Commonwealth Games investment, Clyde Fastlink, the City of Glasgow College, further rail improvements and the M8, M73 and M74 work. (Derek Mackay MSP, SP OR 9 February 2012, col. 6282)

As demonstrated above, the SNP-led Scottish Government's ongoing investment in the Games was often used to counter opposition arguments about a lack of investment in Glasgow's infrastructure and transport system, thus countering the frequently-cited argument from Labour about 'Scotland being on pause' during the referendum due to the SNP's focus upon securing a 'Yes' vote.

One strategy of particular interest for the current study was the SNP's use of the Games to illustrate problems with the constitutional status quo, aligning with the party's 'means-goal' discursive strategy of highlighting the risks of continued Union due to a 'No' vote. A prime example of this strategy was using the Games to argue for gaining control over Air Passenger Duty, suggesting the event would have its potential tourism benefits for Scotland hampered by a prohibitive rate of APD:

The Commonwealth Games in Glasgow - the Ryder Cup and of course Scotland's Year of Homecoming 2014 are going to be potentially huge boosts. However there is still a blight over air travel to and from Scotland in the shape of the Air Passenger Duty... which Westminster not only continues to levy on Scotland but has astonishingly increased it in the Autumn Statement... If Scotland had powers to set our own APD rates we could give our aviation industry and travellers a better and fairer deal, cheaper holiday costs and businesses a competitive tax regime which is more in line with mainland European nations. It is clear that this can only be delivered with a Yes vote next September. ('2014 Tourismhit by Westminster's Air Travel Tax', SNP press release, 2014) 
Similar arguments were made in relation to the allocation of Value Added Tax revenues within the UK, arguing that the additional VAT revenues from Gamesrelated tourist expenditure would go to the UK Treasury despite the Scottish Government's investment in the Games:

Some of this is complicated by the current devolution settlement because we don't get the money back in VAT to spend, or anything such as that. Y'know, post-independence it really takes off... We're not able to invest on the basis of getting a return. We only get the allocated spend, so we put all that money in but we don't get the benefit back. (Kenny MacAskill MSP, interview)

The examples regarding APD and VAT are therefore used to reinforce the SNP's 'public narrative' of the constrained economic circumstances of the status quo, with the need for additional fiscal powers 'in Scottish hands' to eradicate the 'democratic deficit' (Leith and Soule, 2011; Pittock, 2008). This narrative evokes the arguments of Kedourie $(1960,1971)$ and his conceptualisation of the 'ideological' form of nationalism which emphasises political self-determination, and provides further justification for arguments regarding the centrality of such arguments in the SNP's political strategy (Casanas Adam, 2014; Dalle Mulle, 2016; Keating, 2012; Mycock, 2012). Other examples of the SNP using the Games to highlight problems with Scotland's constitutional status included emphasis on the non-allocation of Barnett formula spending consequentials to Scotland deriving from the additional Government spending and Lottery funding relating to the London 2012 Olympics, highlighting the lack of a British and/or Scottish constitution in comparison to other independent Commonwealth countries, and emphasising the expanded opportunities for Scottish athletes as part of 'Team Scotland' at the Commonwealth Games in 
contrast to their restricted opportunities as part of 'Team GB' at the Olympic Games (Jarvie and Reid, 1999).

Despite this emergent pattern, both SNP interviewees expressed only qualified support for the logic that the Games had the potential to impact on support for a 'Yes' vote, rightly arguing the impact of the Games was minimal in comparison to other substantive policy areas and political debates. Nonetheless, there was a shared belief that the success of the Games would result in a 'feel-good factor' within Glasgow and Scotland, echoing the arguments of Grix (2014) and Jarvie (2017) on the use of such events for 'feel-good purposes, with MacAskill in particular arguing that this positivity would boost the 'Yes' vote:

I think that anything that makes Scots feel confident because I think the majority of people in Scotland have always wanted to vote 'yes'. Some of it's just... we don't know, can't conceptualise or worry about being too wee, too difficult... so anything that raises the profile, raises selfconfidence, shows that we can do it, can compete... we can run the best ever Commonwealth Games, why can't we run our own country? (Kenny MacAskill MSP, interview)

Although adopting a more sceptical stance, Mason still echoed the belief that the Games' success had resulted in greater self-confidence within the Scottish population, boosting the pro-independence campaign:

I don't really think they were a major factor. I mean I think there was a kind of feel-good thing. I think there was... this process of building up our self-confidence that we can do these things... and I feel that's been quite a crucial part of the referendum, but the Games is definitely part of that process of our self-confidence. (John Mason MSP, interview) 
For the SNP, the successful organisation of the Games acted as an illustration of Scotland's capacity for political self-governance, contributing to a longer-term trend of growing confidence due to the perceived success of the devolved Scottish Parliament as part of the 'gradualist' movement towards political independence (Casanas Adam, 2014; Dalle Mulle, 2016; Hearn, 2014; Keating, 2012; Leith and Soule, 2011; Leith and Steven, 2010; McGarvey and Cairney, 2008).

\section{Scottish Labour and the Politics of the Games - 'Glasgow's Games', Scrutinising the SNP and the 'Best of Both Worlds' Narrative}

Attention now turns to the Labour's discourse on the Games. This sample was based on the party's 2 main policy documents on the topic of the Scottish constitution, 'Together We Can' and 'Powers for a Purpose', 3 election manifestos from the preGames period, as well as 120 parliamentary speech contributions and 17 press releases which make explicit reference to the Games.

One of the most significant findings of the analysis is the additional emphasis placed on the sporting legacy of the Games by Labour, differentiating the party from the SNP's discursive strategy which prioritised the economic legacy to a greater extent. For example, analysis of Labour's discourse sample identified that the majority of the references to the Games' benefits and/or legacy were sport-related, significantly outstripping the 'economic', 'profile and reputation' and 'other' categories. Particular emphasis was placed on the importance of using the Games as a catalyst to boost sports or physical activity participation: 
The 2014 Commonwealth Games in Glasgow in particular present Scotland with a great opportunity to unleash a revolution in sporting involvement. In preparing for a successful Games, we must ensure our athletes enjoy the benefits of competing at home and we must build towards a lasting legacy for Scotland's citizens. The run-up to the Games should be used both to highlight the country's poor record on physical activity and associated ill-health, and as a springboard for a vast improvement in our nation's wellbeing. (Scottish Labour Sports Manifesto, 2011: 1)

Labour also highlighted other aspects of the sporting benefits and legacy of the Games within their discourse, additionally citing the health benefits of sports participation, the benefits for Scotland's elite sports performance system, sports volunteering opportunities and sports facility development, despite the questionable evidence upon which such claims are founded (Clark and Kearns, 2016; Matheson, 2010; McCartney et al., 2012; Owe, 2012; Stewart and Rayner, 2016).

Despite the clear emphasis on a sporting legacy in Labour's discourse, the party did partially echo the arguments of the SNP regarding the economic considerations for hosting the Games. The main arguments forwarded by Labour related to the benefits of the Games for Scottish tourism and regeneration of Glasgow's 'East End' (Christie and Gibb, 2015; Matheson, 2010; Rogerson, 2016). Indeed, a narrative which became apparent in Labour's discourse regarding the economic impact of the Games was the framing of the event as a solution to the failures of the SNP's economic strategy:

Spending on construction and refurbishment of Games venues and the Athletes' village now supports around 1000 jobs including more than 600 new jobs and 700 new houses including support specifically designed to get people who are long-term unemployed back into work. The regeneration of the East End of our city is exactly the type of project that will help get our economy growing again and help stop the tragedy of 
young people leaving school and being forced to join the long queue of unemployed. ('Dalmarnock Regeneration is Example of How Government Can Boost the Economy and Our Communities Without Obsessing Over the Constitution', Scottish Labour press release, 2013)

In contrast to the SNP, the interviews with Ferguson and Smith highlighted a greater emphasis on the benefits of the Games for Glasgow. This is perhaps unsurprising given that both interviewees represent Glasgow constituencies and regions, combined with the relative strength of Labour in Glasgow at the time of the Games in terms of MSPs, MPs and the Labour-led Glasgow City Council. This partial skewing towards the reputational benefits of the Games for Glasgow over Scotland in the part's discourse therefore appears to be both pragmatic and political in nature, grounded in both the realisation that the Games impact would ultimately be centred on the Glasgow context for visitors whilst also reflecting the political considerations of the Labour party in Glasgow (Leith and Soule, 2011; Mooney et al., 2015).

The contrasting viewpoints on this debate can be linked to the wider political strategies of the parties involved, with Labour primarily emphasising the benefits of the event for Glasgow:

...I think certainly as a Glasgow Labour Party and a Scottish Labour Party, we always saw the bid as also being about, not to the exclusion of anything else, but a significant part of our drive was about how we brought investment into the city and how we could use the Games in a way that allowed us to present the city on an international stage. And we hoped to draw benefits from that, but also to make a particular regeneration impact in the East End. (Drew Smith MSP, interview)

This pattern was also evident in the nature of the party's discourse regarding the organisational successes of the Games, representing a discursive battle to reap 
political credit for the success of the event. Labour frequently highlighting the importance of partnership working and the contributions of the Labour-led Glasgow City Council in the delivery of the event, echoing the arguments of Christie and Gibb (2015):

And, of course, there is the Commonwealth Games - delivered by a Labour council and a proud city. ('Speech to Scottish Labour Conference by Johann Lamont MSP', Scottish Labour press release, 2014)

Another important aspect was the role that was played by Glasgow City Council and, indeed, by councillors, officials and businesspeople-not only in Glasgow, but across Scotland and in other parts of the UK, as well as by the previous First Minister, Jack McConnell... (Hanzala Malik MSP, SP OR 7 August 2014, col. 33224)

Although many of these debates over the political credit for the Games remained relatively sedate, at points this aspect of the event's politicisation became more heated, particularly within parliamentary debates:

The Games are for Glasgow, in particular, but I am a little fearful that they might be hijacked by others. There is a huge temptation for other cities, and for people who have perhaps not been fully involved, to try to hijack the Games. We need to recognise that, in the main, it is Glasgow that has done all the running for the Games. (Hanzala Malik MSP, SP OR 30 January 2014, col. 27246)

The Games' interconnection with the perceived competence of the leading proindependence and pro-union parties clearly demonstrated an indirect link to the arguments forwarded in the campaigns about the ability of the SNP to successfully govern an independent Scotland, indicating that all parties imbued the Games with at least a modicum of political importance despite arguments to the contrary. 
Analysis of Labour's discourse also identified numerous instances where the event was used as an example to illustrate wider political issues. In particular, the Games were frequently used as a justification for criticism of the SNP government on a range of political issues:

...Glasgow City Council has done a fantastic job preparing our city for the events... The achievement is even more impressive when you consider the massive financial constraints that have been put on our city, year after year. Despite the Scottish Government taking more than $£ 150$ million from our city’s finances, Glasgow has used the Games to create real, sustainable jobs, from Govan to Garrowhill, through the Glasgow Guarantee. ('Glasgow is Using the Commonwealth Games', Scottish Labour press release, 2014)

In addition to these criticisms regarding council funding (Mooney et al., 2015) and the cancellation of the Glasgow Airport Rail Link, Labour also used the Games to raise issues relating to transport investment issues, Police Scotland control rooms, the National Planning Framework, teacher numbers, NHS budgeting debates, and the future of the BBC in Scotland. This criticism of the SNP-led Scottish Government can therefore be argued to constitute an attempt by Labour to create a counternarrative which aims to undermine the SNP's own attempts to illustrate its competence to govern an independent Scotland (Cairney, 2011; Dardanelli and Mitchell, 2014; Johns et al., 2013; Larkin, 2011; Leith and Soule, 2011).

Labour's discourse also contained a number of contrasting positions and comments on the implications of the event with regards to Scotland's constitutional status. In particular, the party considered the potential symbolism of the Games for the 
constitutional debate, with a number of references alluding to the benefits of the union for the Games and Scottish sport:

\begin{abstract}
Many sports are supported at a UK level, with UK-wide facilities. There is also tremendous UK co-operation and camaraderie in all sports. The Olympics provided the template and the platform for the games and both were utilised in the planning of Glasgow 2014; it also encouraged the growth of public interest in a wide range of sports... We now have to take the combined achievements of the UK and its nations, competing together and in friendly rivalry, and build on that to take Scottish and UK sport to the next level. (John Pentland MSP, SP OR 7 August 2014, col. 33201-33202)
\end{abstract}

The symbolism of the event for the maintenance of British identity was also emphasised by Labour, echoing the arguments of the wider pro-union campaign that supporting the union can be viewed as a patriotic act:

\begin{abstract}
Manchester has also hosted a fantastically successful Commonwealth Games. Glasgow, I'm sure, will host an equally, if not even more spectacular Games in just a couple of weeks. Glasgow, Manchester, and London: three great cities we welcome into our homes every week with River City, Coronation Street and EastEnders... The Nationalists would have you believe that these characters, represented in television drama, are so different as to demand separation; a new border and a new psychological wound opened between Scotland's communities and those of our neighbours in Manchester and London... the nationalists want this referendum debate to be Scotland $\mathrm{v}$ Britain. But the true choice is between two Scottish visions of Scotland's future: a nationalist vision that severs all political links with Britain, and a patriotic vision of a Scottish Parliament that is part of a system of pooling and sharing risks and resources across the UK. ('What EastEnders and River City can teach the Nats', Scottish Labour press release, 2014)
\end{abstract}

The complex nature of Scottish identity was also referred to in Smith's interview, making reference to the distinctive nature of the Games given the existence of a separate Scottish team: 
I think it's important that we do compete as a home nation in Games like the Commonwealth... I think it's an important thing that it allows people to feel that we can have both of those. We can compete as Team GB at the Olympics but we can also have the benefit of competing as Scotland as well at different times, and I think that that balance and that mixture is what makes the Commonwealth Games for the home nations

... it agrees my view on the constitution where you don't have to make that choice, you can have both. (Drew Smith MSP, interview)

This position therefore illustrates that the Labour's constitutional narrative regarding the union as the 'best of both worlds' is replicated symbolically at events such as the Games (Jarvie, 2017; Jarvie and Reid, 1999; McDowell and Skillen, 2017; Ochman, 2013). This 'best of both worlds' narrative appears to have a dual purpose. Firstly, it again emphasises the positives of the union for Scotland by stressing the economic security gained from the UK (Sharp et al., 2014), while, secondly, the 'pooling and sharing of resources' trope underlines a vision of the UK which aligns with Labour's ideological values of 'unionist nationalism' (Ichijo, 2012). Such arguments are representative of the party's political position on the Games, with an emphasis placed on refuting the attempts of the SNP to exploit the Games for political purposes whilst acknowledging the potential implications, if limited, of the Games for the referendum campaign.

\section{Conclusions}

The analysis of the respective parties' political discourse on the 2014 Commonwealth Games illustrated nuanced positions on the event. For the SNP-led Scottish Government, emphasis in their narrative was focused upon both the sporting and economic legacy of hosting the Games, demonstrating an adherence to the 
'boosterism' logic which has often been argued to underpin political justifications for hosting major sporting events (Holt, 1989; Horne, 2007; Horne and Manzenreiter, 2006; Zimbalist, 2015). In contrast, Labour placed greater emphasis on the sporting legacy of the Games, with less emphasis placed on the economic benefits of the event. However, despite the abundance of evidence which suggest such legacy claims often fail to come to fruition (Giulianotti, 2016; Horne, 2007; Horne and Manzenreiter, 2006; Martin and Barth, 2013; Stewart and Rayner, 2016; Zimbalist, 2015), neither party adopted a critical or oppositional stance with regards to the hosting of the Games in the public domain. However, interviewees did express some reservations on the validity of the espoused benefits of the event in private, suggesting that a degree of self-censorship was exercised to avoid alienating the public given the popular consensus supporting the Games.

Given the extended nature of the Scottish independence referendum campaign and the exhaustive list of issues which became politicised by both sides of the debate (ranging from central issues of economics, currency, defence, and social justice to relatively marginal issues such as broadcasting rights of $\mathrm{BBC}$ programming, the future of the 'Union Jack' flag and Scottish representation at the Olympic Games), it is striking that the 2014 Games remained one of the few issues mutually declared as apolitical (Jarvie, 2017; Mole, 2014). However, despite the predominantly apolitical nature of the Games, there were some examples whereby the event was used by the respective parties to illustrate a particular ideological or political position within Scotland-wide or regional politics. For example, the Games were often used as an analogy to illustrate a wider political issue, with issues such as the negative impact of Air Passenger Duty for the SNP, or the impact of council funding cuts for the 
Labour. Furthermore, the Games were also explicitly linked to the wider constitutional debate, with the SNP using the success of the Games as an example of the potential and competence of an 'imaginary' of an independent Scotland, and Labour using the Games to illustrate the 'best of both worlds' public narrative of the constitutional status quo given the support of the UK Government for the Games and the dualistic symbolism of the event for expressions of Britishness and Scottishness (Jarvie, 2017; Ochman, 2013). Despite the fact that this political exploitation of the 2014 Games made little impact on the final result, with the result of a $55.3 \%$ 'No' vote and a 44.7\% 'Yes' vote surely proving too significant a margin for an event such as the Commonwealth Games to have any sort meaningful influence, the findings outlined above demonstrate the potential to capitalise on events such as the Games for contrasting political purposes.

\section{References}

Almeida, B., Marchi Junior, W., and Pike, E. (2014). The 2016 Olympic and Paralympic Games and Brazil's soft power. Contemporary Social Science, vol. 9 (2), 271-283.

Bateman, D., and Douglas, D. (1986). Unfriendly Games: Boycotted and Broke: The Inside Story of the 1986 Commonwealth Games. Edinburgh: Mainstream Publishing Projects and Glasgow Herald.

BBC News (2014). Scottish independence: call for 'truce' during Glasgow 2014. BBC News Online. http://www.bbc.co.uk/news/uk-scotland-scotland-politics- 
Black, D. (2014). Megas for strivers: the politics of second-order events. In J. Grix (ed.), Leveraging Legacies from Sports Mega-events: Concepts and Cases, 13-23. Basingstoke: Palgrave Macmillan.

Boffey, D. (2014). Nicola Sturgeon: Commonwealth Games feelgood factor is a confidence boost for yes campaign. The Observer. http://www.theguardian.com/ politics/2014/aug/02/nicola-sturgeon-commonwealth-games-confidence-boostscotland-yes-independence. [Accessed 8 August 2016]

Brannagan, P.M., and Giulianotti, R. (2014). Qatar, global sport and the 2022 FIFA World Cup. In J. Grix. (ed.) Leveraging Legacies from Sports Mega-events: Concepts and Cases, 154-165. Basingstoke: Palgrave Macmillan.

Cairney, P. (2011). Coalition and minority government in Scotland: lessons for the United Kingdom? The Political Quarterly, vol. 82 (2), 261-269.

Casanas Adam, E. (2014). Self-determination and the use of referendums: the case of Scotland. International Journal of Politics, Culture and Society, vol. 27, 47-66.

Christie, L., and Gibb, K. (2015). A collaborative approach to event-led regeneration: the governance of legacy from the 2014 Commonwealth Games. Local Economy, vol. $30(8), 871-887$. 
Clark, J., and Kearns, A. (2016). Going for gold: a prospective assessment of the economic impacts of the Commonwealth Games 2014 on the East End of Glasgow. Environment and Planning C: Politics and Space, vol. 34 (8), 1474-1500.

Cornelissen, S. (2010). The geopolitics of global aspiration: sport mega-events and emerging powers. The International Journal of the History of Sport, vol. 27 (16-18), $3008-3025$.

Dalle Mulle, E. (2016). New trends in justifications for national self-determination: evidence from Scotland and Flanders. Ethnopolitics, vol. 15 (2), 211-229.

Dardanelli, P., and Mitchell, J. (2014). An independent Scotland? The Scottish National Party's bid for independence and its prospects. The International Spectator, vol. 49 (3), 88-105.

Dheenshaw, C. (1994). The Commonwealth Games: The First 60 Years 1930-1990. Harpenden: Queen Anne Press.

Fairclough, I., and Fairclough, N. (2012). Political Discourse Analysis: A Method For Advanced Students. London: Routledge.

Giulianotti, R. (2016). Sport: A Critical Sociology. Cambridge: Polity Press, second edition. 
Gray, N., and Mooney, G. (2011). Glasgow's new urban frontier: 'Civilising' the population of 'Glasgow East'. City, vol. 15 (1), 4-24.

Gray, N., and Porter, L. (2015). By any means necessary: urban regeneration and the "state of exception" in Glasgow's Commonwealth Games 2014. Antipode, vol. 47 (2), 380-400.

Grix, J. (2013). Sport, politics and Olympics. Political Studies Review, vol. 11, 15-25.

Grix, J. (2014). Preface: why do states invest in sports mega-events? In J. Grix (ed.), Leveraging Legacies From Sports Mega-events: Concepts and Cases, x-xii. Basingstoke: Palgrave Macmillan.

Grix, J., and Houlihan, B. (2013). Sports mega-events as part of a nation's soft power strategy: the cases of Germany (2006) and the UK (2012). The British Journal of Politics \& International Relations, vol. 16 (4), 572-596.

Harris, J., and Skillen, F. (2016). Sport, gender and national identities. In N. Blain, D. Hutchison, and G. Hassan (eds.), Scotland's Referendum and the Media: National and International Perspectives, 83-96. Edinburgh: Edinburgh University Press.

Hearn, J. (2014). Nationalism and normality: a comment on the Scottish independence referendum. Dialectical Anthropology, vol. 38 (4), 505-512. 
Holt, R. (1989). Sport and the British: A Modern History. Oxford: Oxford University Press.

Holt, R., and Ruta, D. (eds.) (2015). Routledge Handbook of Sport and Legacy: Meeting the Challenge of Major Sports Events. London: Routledge.

Horne, J. (2007). The four 'knowns' of sports mega-events. Leisure Studies, vol. 26 (1), 81-96.

Horne, J. (2017). Sports mega-events - three sites of contemporary political contestation. Sport in Society, vol. 20 (3), 328-340.

Horne, J., and Manzenreiter, W. (2006). An introduction to the sociology of sports mega-events. The Sociological Review, vol. 54, 1-24.

Ichijo, A. (2012). Entrenchment of unionist nationalism: devolution and the discourse of national identity in Scotland. National Identities, vol. 14 (1), 23-37.

Iorwerth, H., Hardman, A., and Rhys Jones, C. (2014). Nation, state and identity in international sport. National Identities, vol. 16 (4), 327-347.

Jarvie, G. (2017). Sport, the 2014 Commonwealth Games and the Scottish referendum. In A. Bairner, J. Kelly and J.W. Lee (eds.), The Routledge Handbook of Sport and Politics, 209-221. London: Routledge. 
Jarvie, G., and Reid, I. (1999). Scottish sport, nationalist politics and culture. Culture, Sport, Society, vol. 2 (2), 22-43.

Jeffreys, K. (2012). Sport and Politics in Modern Britain: The Road to 2012. London: Palgrave Macmillan.

Johns, R., Mitchell, J., and Carman, C. (2013). Constitution or competence? The SNP's re-election in 2011. Political Studies, vol. 61 (S1), 158-178.

Keating, M. (2012). Rethinking sovereignty. Independence-lite, devolution-max and national accommodation. Revista d'Estudis Autonomics i Federals, vol. 16, 9-29.

Kedourie, E. (1960). Nationalism. London: Hutchinson.

Kedourie, E. (ed.) (1971). Nationalism in Asia and Africa. London: Weidenfeld and Nicolson.

Kidd, B. (1988). The campaign against sport in South Africa. International Journal, vol. 43 (4), 643-664.

Larkin, P. (2011). The politics of coalition in Scotland. Political Science, vol. 63 (1): $61-78$

Leith, M.S., and Soule, D.P.J. (2011). Political Discourse and National Identity in Scotland. Edinburgh: Edinburgh University Press. 
Leith, M.S., and Steven, M. (2010). Party over policy? Scottish nationalism and the politics of independence. The Political Quarterly, vol. 81 (2), 263-269.

Lynch, P. (2009). From social democracy back to no ideology? The Scottish National Party and ideological change in a multi-level electoral setting. Regional \& Federal Studies, vol. 19 (4-5), 619-637.

Majumdar, B. and Mehta, N. (2010). Sellotape Legacy: Delhi and the Commonwealth Games. Noida: Harper Collins.

Manzenreiter, W. (2010). The Beijing games in the western imagination of China: the weak power of soft power. Journal of Sport and Social Issues, vol. 34 (1), 29-48.

Martin, A., and Barth, K. (2013). Resident perceptions of sport mega-events: a host community perspective on the forthcoming Commonwealth Games in Glasgow 2014. Event Management, vol. 17 (1), 13-26.

Matheson, C. (2010). Legacy planning, regeneration and events: the Glasgow 2014 Commonwealth Games. Local Economy, vol. 25 (1), 10-23.

McCartney, G., Hanlon, P., and Bond, L. (2012). How will the 2014 Commonwealth Games impact on Glasgow's health, and how will we know? Evaluation, vol. 19 (1), 24-39. 
McDowell, M., and Skillen, F. (2017). The 1986 Commonwealth Games: Scotland, South Africa, sporting boycotts, and the former British Empire. Sport in Society, vol. $20(3), 384-397$.

McGarvey, N., and Cairney, P. (2008). Scottish Politics: An Introduction. Basingstoke: Palgrave Macmillan.

McPherson, G., O’Donnell, H., McGillivray, D., and Misener, L. (2016). Elite athletes or superstars? Media representation of para-athletes at the Glasgow 2014 Commonwealth Games. Disability \& Society, vol. 31 (5), 659-675.

Misener, L., McGillivray, D., McPherson, G., and Legg, D. (2015). Leveraging parasport events for sustainable community participation: the Glasgow 2014 Commonwealth Games. Annals of Leisure Research, vol. 18 (4), 450-469.

Mishra, S. (2012). 'The Shame Games': a textual analysis of Western press coverage of the Commonwealth Games in India. Third World Quarterly, vol. 33 (5), 871-886.

Mishra, S. (2013). Projections of power, news framing, and India's 2010 Commonwealth Games. Howard Journal of Communications, vol. 24 (2), 178-193.

Mole, S. (2014). Editorial: Glasgow, the referendum and the Commonwealth Games. The Round Table, vol. 103 (5), 453-455. 
Mooney, G., McCall, V., and Paton, K. (2015). Exploring the use of large sporting events in the post-crash, post-welfare city: a 'legacy' of increasing insecurity? Local Economy, vol. 30 (8), 910-924.

Mycock, A. (2012). SNP, identity and citizenship: re-imagining state and nation. National Identities, vol. 14 (1), 53-69.

Nye, J. (2004). Soft Power: The Means to Success in World Politics. New York, NY: Public Affairs.

Ochman, K. (2013). Commonwealth Games and their impact on Scotland's future in or outside the United Kingdom. International Studies, vol. 15 (1): 75-85.

Owe, E. (2012). Legacy Lessons From Past Large-scale Sporting Events: Review of Evidence. Edinburgh: Scottish Government. http://www.gov.scot/Publications/2012/ 10/7250. [Accessed 8 August 2016]

Paton, K., Mooney, G., and McKee, K. (2012). Class, citizenship and regeneration: Glasgow and the Commonwealth Games 2014. Antipode, vol. 44 (4), 1470-1489.

Pittock, M. (2008). The Road to Independence? Scotland Since the Sixties. London: Reaktion.

Polley, M. (2014). Introduction: the Empire and Commonwealth Games and the challenge of history. Sport in History, vol. 34 (3), 383-389. 
Reid, G. (2013). When it's gone it's gone: the politics of the Save Meadowbank Stadium Campaign. Local Economy, vol. 28 (6), 627-642.

Reid, G. (2014). Save Meadowbank stadium: the politics of local stadium closure. International Journal of Sport Policy and Politics, vol. 6 (1), 37-54.

Rogerson, R. (2016). Re-defining temporal notions of event legacy: lessons from Glasgow's Commonwealth Games. Annals of Leisure Research, vol. 19 (4), 497-518.

Scottish Government (2015). The Scottish Health Survey 2014. Edinburgh: Scottish Government. http://www.gov.scot/Publications/2015/09/6648/downloads. [Accessed 8 August 2016]

Sharp, J., Cumbers, A., Painter, J., and Wood, N. (2014). Deciding whose future? Challenges and opportunities of the Scottish independence referendum 2014 for Scotland and beyond. Political Geography, vol. 41, 32-42.

Stewart, A., and Rayner, S. (2016). Planning mega-event legacies: uncomfortable knowledge for host cities. Planning Perspectives, vol. 31 (2), 157-179.

Survation (2014). New Scottish referendum poll - no 'Commonwealth Games Boost' for 'Yes' campaign, Survation. http://survation.com/no-commonwealth-games-boostfor-yes-campaign-new-scottish-independence-referendum-poll/. [Accessed 8 August 2016] 
Tomlinson, J. (2014). Imagining the economic nation: the Scottish case. The Political Quarterly, vol. 85 (2), 170-177.

Wade, M. (2014). Politicians on both sides fail to keep the referendum out of Games speeches, The Times Scotland Online. http://www.thetimes.co.uk/tto/news/uk/ scotland/article4155220.ece. [Accessed 8 August 2016]

Zimbalist, A. (2015). Circus Maximus: The Economic Gamble Behind Hosting the Olympics and the World Cup. Washington, D.C.: Brookings Institution Press. 